\title{
Expression of spiritual experiences in art
}

\author{
Nasirov Azimiddin Normamatovich ${ }^{1}$ \\ ${ }^{1}$ Uzbekistan, Samarkand State University, Doctor of Philology
}

\section{ABSTRACT}

The artistic interpretation of the human spirit in a work of art is analyzed on the example of the works of later years. The article focuses on the analysis of the heartache, the contradictions in the inner world, based on the story of the fugitive Norqobil, which describes the realities of the Afghan war. During the analysis, the influence of time and environment on the occurrence of conflicts in the human heart was highlighted.

Keywords: psyche, art, interpretation of tragedy, artistic hero, image method, life and man.

\section{Introduction}

Although the concept of life and man is expressed in a dialectical unity, the existence between them determines the way a person thinks, his worldview. Life existence serves man to live, to think, to struggle, to understand justice and injustice. The sages claim that a person's whole life is insufficient to understand the ups and downs of life, black and white. The question arises as to whether this truth can be the same for everyone. We believe that the answer to this question can be found in the works of artists. After all, any work of art is a reflection of life, and even if there is a drop in it, of course, the reality of life is less reflected. The writer Kochkar Norqobil, who experienced the hardships of the two years of the Afghan war, described the complexities of life, the contradictions in the inner world of man, and the bitterness of life for several years. In most cases, when reading works devoted to the subject of war, readers pay attention to how the war is fought, the battles in the battles. In fact, the purpose of every writer's approach to this topic is to identify the factors that lead to changes in the human psyche, to clearly demonstrate its negative consequences.

\section{Main part}

As the literary critic Umarali Normatov noted: So far, unlike the works written on the theme of war, we do not divide heroes into whites and reds, enemies and ours, winners and losers. War is a brutal way of resolving interstate majorities, a shameful exercise against human nature and dignity. War is a calamity, destruction, loss, tragedy for both sides (p. 1, 66). From this point of view, the writer K.Norqobil gives a well-grounded artistic interpretation of human tragedy in the play.

In the literature of the following years, a number of works on the theme of war were created, in which the contradictions of life, changes in human thinking, the absence of defeats and victories were expressed. These features can be seen in the very deep interpretation of Kochkar Norqobil's story behind the river.

The protagonist is a newcomer to the war, eager to fight like a soldier, to show heroism, to see what the battle will be like, and to do it every day: to wash dishes in the kitchen every day, to worry about going from the warehouse to the grocery store. we preferred. Who knows, a person will always be in a hurry to see the inevitable events that happen in front of him? (Pp. 2, 6).

A soldier who is trustworthy and compassionate before the start of the war will be amazed when he sees the brutality in the regiment. He still did not know, did not understand, did not feel that tomorrow he would be just as unkind. That social environment was slowly attracting and nurturing them. The upbringing of this environment, on the other hand, consisted of cruelty, of turning man against man, of sacrificing them for the sake of fewer interests.

"Somehow, it's still unknown to you, but panic is inevitable. Diling betaskin. A flower in your heart. Anxiety grows every minute. How difficult it is to prepare for future risks" (pp. 2, 12). It is clear from this passage from the play that the previous interest in our protagonist is counted and replaced by anxiety. This anxiety was preceded not only by the fear of losing a little life, but also by the feeling of being prematurely separated from his family, his parents, not from heroism, not from courage, but from humiliating death in foreign lands. A soldier's days of war, bloodshed, and loss disturbed his peace. The events of the day shake the heart of a young man who has just entered life. Without realizing it, he begins to feel the cruelty of life. Even at night, in his dreams, he struggled little by little, confused. He would spend the nights restlessly.

"It was as if the car was covered in blood, and my parents and siblings were swimming in it. And I'm standing at the top of the gate watching them. That's my father, then my brother. I stare at my mother's face in the bloody whirlpool. He disappeared too. Tagin came out in a whirlwind. Red-haired Mother-jooon !!! O-o-o !!!" (2, 18-b).

In the brutal beating of the Afghans, the young men were dying physically or mentally. These guys couldn't figure out what would happen in the battle tomorrow, who would survive and who would get it. He is slowly beginning to feel that he will not be able to stand with his brothers, who are in the same line today. Based on the analysis of the work, it is possible to understand that in the face of many casualties, the soldiers' hearts were hardened, and they were ruthless in order to save their lives. Although they were a little saddened by the loss of their comrades, gradually, in the words of the author, the Warriors fell asleep as if nothing tragic had happened. This is not a sign of selfishness in them, but a lack of confidence in the future, in the future. Gradually he begins to realize that a wound inflicted on the body can be treated with medicine, but that a wound inflicted on the spiritual world cannot be healed. War veterans are very different from those who lived a peaceful life. Even when they return from the war, the memory of their days does not leave them in peace. The author very convincingly interprets that in most of them a mental crisis can be observed:

"You don't look human in war, you only remember that you are human and insulted when it's all over. The 
agony of memory will torment you until the last moments of your life, when you realize that war has always been victorious, that all those who took part in the war were defeated and died" (p. 2.53). This means that there is not enough time to forget these sufferings, as the experiences of the war are etched in the memory of a person for a lifetime, and from time to time, as the years go by, they become annoying. Moral harm can lead to the loss of a person's minority, the breakdown of his will. If the will is broken, then it is natural that the person's confidence in the present and his hopes for the future will gradually break down: " It is always painful for a person to repeat something that has torn his heart. Because your conglomerate will be adorned. How horrible it must be to set foot again in a place that has suffered a loss in war. It seems to you that a scientist can come out of a roparang. How hard it is for you to feel at every moment that the day is over, that you will never have another chance to see this bright world. As you fight with yourself, the walls of your will begin to crumble" (2.39-b). The author portrayed Gavrilov as a man with a broken will. People like Gavrilov are mute people who have escaped any hardships and are able to do anything just to survive: "they have lost their little human image: the nature of war is such that its participants have already lost their little human image" (1, p. 51). Although the protagonist of the story often seemed to retreat a little from his advice, his will was much stronger. When he entered the war, not only did he think a little, but his family, who were eagerly awaiting him in his homeland, mourned his duty to his parents: "I do not want to take! I will survive in any situation. I will return to my parents and my country safe and sound. I am my father's support. $\mathrm{O}$ God, do not rub and take away in these places" (2.31-b). Indeed, it is their duty to their parents, their prayer, that saves the soldier from danger. The protagonist of the work experiences a very severe mental agony. He begins to feel more deeply that war is not without casualties. Only the notion of time would cure his pain.

As the fugitive Norqobil describes, the protagonists were dissatisfied with the Afghan war and the bloodshed. In the war, young men of different nationalities fought, but did not understand why or for whom they were fighting. They were convinced that the efforts of the Soviet government under the guise of internationalism were not in line with the original reality. The soldiers, who witnessed such actions of the government, created hatred and mistrust in them. In particular, the soldiers, who came to foreign journalists, correspondents and politicians to find out about the condition of the Soviet soldiers, reacted as if with false pleasure: "This artificial, false attempt provoked anger. We hid the fact that we were wandering in strange places. We did not admit that we were the aggressors of the truth. I felt that I was attacking my relatives, who had the same true religion and beliefs, and harassing their Muslim children. But I was an Uzbek soldier at the behest of the Russian army, "he said (1, pp. 20-21). Not only the Uzbek soldiers, but all the soldiers of all nationalities associated with this red empire did not have the will. They come to life in our minds as helpless people, helpless individuals involved in war for the benefit of a certain limited group. The warriors wanted to live. They saw themselves as soup-eaters who were oppressed by the politics of the time wearing the mask of the Motherland.

"We have been shamefully deceived, mentally crippled, now I know. In short, the Kremlin's sins were on the rise. Because the young men who had just recognized black and white were dying here, and the living had been taken away". It can be seen that the author repeatedly repeats the phrase in his works about the Afghan war that the living also took over. After every battle, the living soldiers will see the blood shed innocently, the places destroyed, the children orphaned. So the young men, who were helpless in the face of the politics of the time, were forced to suffer such sufferings.

\section{Conclusion}

In short, the human psyche is a complex system. This system can evolve under the influence of many factors. Young people under the age of twenty, in particular, tend to understand the minority, know their worth, and define their attitudes toward others. In the story of "Crying on the other side of the river," young people who are growing up are thrown into the grip of war, and as a result, their mentality changes radically. High aspirations are replaced by small aspirations. A sense of confidence turns into insecurity. Bitter memory always hurts. Of course, the difficulty of overcoming these crises is reflected in the character of the protagonists. Suffering in the human psyche is interpreted very artistically.

\section{References:}

1.Normatov U. Promising principles. -T .: "Spirituality", 2000. -112 p.

2.Quchqor Norqobil. Who Wakes the Sun ?: Stories. -T .: "East", 2007. -384 p.

3.Rasulov A. Art is a novelty. -T., "Sharq", 2007. - 336 p.

4.Serif Aktash. Introduction to novel art and novel insemination. - Ankara, 1991. - 162 B.

5.Izzat Sultan. Literary theory. - T., "Teacher", 2005. -272 p.

6.Faryono J.Vvedenie v literatturovedenie. Wster do literaturoznawstwa. - Wyd. II. - Warszawa, 1991. 